\title{
MAKNA PENCAPAIAN PRESTASI BELAJAR PADA MAHASISWA PROGRAM PASCASARJANA DENGAN PERAN GANDA
}

\author{
ERVIN NURUL AFFRIDA ${ }^{*}$ \& VERONIKA SUPRAPTI ${ }^{2}$ \\ 1Program Studi Magister Psikologi, Fakultas Psikologi Universitas Airlangga \\ ${ }^{2}$ Departemen Psikologi Perkembangan dan Pendidikan, Fakultas Psikologi Universitas Airlangga
}

\begin{abstract}
ABSTRAK
Penelitian ini bertujuan untuk memahami pengalaman dan makna pencapaian prestasi belajar pada mahasiswa Program Pascasarjana dengan peran ganda. Metode yang digunakan adalah metode kualitatif dengan pendekatan fenomenologi. Penelitian ini melibatkan tiga orang mahasiswa perempuan pada Program Pascasarjana yang berstatus menikah dan bekerja dengan indeks prestasi kumulatif diatas 3.50 sebagai kriteria partisipan. Teknik penggalian data dalam penelitian ini adalah wawancara mendalam. Teknik pemantapan kredibilitas yang digunakan adalah member check. Analisis data penelitian menggunakan Interpretative Phenomenological Analysis (IPA). Temuan pengalaman dalam mencapai prestasi belajar pada mahasiswa dengan peran ganda meliputi tertib presensi perkuliahan, mengerjakan tugas tepat waktu, mempersiapkan diri mengikuti ujian, dan melengkapi literatur yang mendukung pembelajaran. Temuan makna dalam mencapai prestasi belajar meliputi meningkatkan harga diri, membuat bangga keluarga, dan mencapai jenjang karir. Berdasarkan hasil temuan dalam penelitian, dapat disimpulkan bahwa pengalaman mahasiswa dengan peran ganda berbeda-beda dalam mencapai prestasi belajar, sehingga pengalaman tersebut juga dimaknai berbeda menurut persepsi masing-masing individu.
\end{abstract}

Kata kunci: makna, prestasi belajar, mahasiswa dengan peran ganda

\begin{abstract}
This research aimed to understand the experience and purpose of academic achievement of graduate students with dual role. This research used qualitative method with phenomenological approach. The study involved three female students at graduate program, who are married, have paid job and have a GPA above 3.50 as the criteria for study participants. Data collection technique was in-depth interviews. Stabilization technique was member check. Research data analysis used Interpretative Phenomenological Analysis (IPA). The results showed that experience of academic achievement include sign in learning, finishing for task, preparing for exams, and complements literature. The result showed that purpose of academic achievement including improving self-esteem, pride for family, and career achievements. Experience of academic achievement of graduate students with dual role is unique, because it depends on how they perceive the achievement itself.
\end{abstract}

Keywords: meaningfulness, academic achievement, graduate students with dual role 
INSAN Jurnal Psikologi dan Kesehatan Mental, 2017, Vol. 2(1), 22-32, doi: 10.20473/jpkm.v2i12017.22-32

Dikirimkan: 19 Januari 2017 Diterima: 31 Mei 2017 Diterbitkan: 26 Juni 2017

Editor: Ilham Nuralfian

*Alamat korespondensi: Jalan Airlangga 4-6, Surabaya, Jawa Timur 60286. Surel: ervin.nurul.affrida2015@psikologi.unair.ac.id

Naskah ini merupakan naskah dengan akses terbuka dibawah ketentuan the Creative Common Attribution License (http://creativecommons.org/licenses/by/4.0), sehingga penggunaan, distribusi, reproduksi dalam media apapun atas artikel ini tidak dibatasi, selama sumber aslinya disitir dengan baik.

\section{PEN D A H U L U A N}

Perubahan sosial diartikan sebagai pergeseran sikap dan perilaku dari faktor-faktor ekologis dan demografis yang mengubah kehidupan masyarakat dari kondisi tradisional menuju masyarakat modern. Salah satu perubahan sosial di masyarakat adalah pergeseran peran perempuan melalui faktorfaktor sosial dan budaya yang berorientasi gender. Istilah gender berbeda dengan jenis kelamin, karena gender mengacu pada dimensi sosial budaya dan jenis kelamin mengacu pada dimensi biologis. Oleh karena itu, individu yang berjenis kelamin perempuan cenderung melakukan seperangkat peran yang biasa dilakukan perempuan, begitu pula sebaliknya pada laki-laki. Pada keluarga konvensional, laki-laki bertugas mencari nafkah sedangkan perempuan bertugas dalam peran tradisional seperti masak, macak, manak (memasak, bersolek, melahirkan anak) (Fakih, 1996). Berdasarkan pandangan tradisional tersebut, peran perempuan ditentukan oleh kemampuannya sebagai pengurus rumah tangga dan sebagai istri.

Perkembangan ilmu pengetahuan dan teknologi menimbulkan perubahan-perubahan fundamental peran perempuan. Salah satu perubahan yang terjadi adalah pergeseran peran perempuan dari peran domestik di keluarga menuju sektor publik. Peran perempuan di sektor publik mencakup peranperannya di berbagai bidang pembangunan. Hal tersebut terakomodasi melalui Peraturan Presiden Republik Indonesia Nomor 9 Tahun 2000 tentang Pengarusutamaan Gender dalam Pembangunan Nasional (PUG), yang berisi kesetaraan dan keadilan gender melalui kebijakan dan program di berbagai bidang pembangunan.

Faktor penawaran yang mempengaruhi peningkatan angka partisipasi kerja perempuan adalah tingkat pendidikan profesional perempuan yang semakin tinggi (Tjiptoherijanto, 1997). Tingkat pendidikan perempuan yang semakin tinggi disebabkan munculnya berbagai kebijakan yang memudahkan perempuan dalam mengakses pendidikan, salah satunya melalui ketersediaan berbagai macam jenjang pendidikan tinggi. Berdasarkan data dari Pangkalan Data Pendidikan Tinggi tahun 2016, jumlah perguruan tinggi berbentuk universitas sebanyak 567 dan 82 diantaranya berada di provinsi Jawa Timur.

Perkembangan perempuan dalam mengakses pendidikan ditunjukkan berdasarkan data Badan Pusat Statistik tentang peningkatan jumlah mahasiswa perempuan yang masuk ke perguruan tinggi dari $6.13 \%$ di tahun 2009 menjadi 6.62\% di tahun 2010. Meningkatnya jumlah perempuan yang menempuh pendidikan juga tercantum dalam data mahasiswa aktif perguruan tinggi negeri tahun 2016 di Provinsi Jawa Timur dalam lingkup Kementerian Riset, Teknologi, dan Pendidikan Tinggi menunjukkan sebanyak 84.010 mahasiswa laki-laki dan 105.219 mahasiswa perempuan. Data mahasiswa aktif perguruan tinggi swasta di lingkungan Kopertis Wilayah VII menunjukkan sebanyak 210.844 mahasiswa laki-laki dan 212.654 mahasiswa perempuan. Berdasarkan data tersebut, dapat disimpulkan 
bahwa jumlah mahasiswa aktif perempuan di Provinsi Jawa Timur didominasi oleh mahasiswa perempuan.

Fenomena jumlah mahasiswa perempuan yang mendominasi di perguruan tinggi, juga ditemukan peneliti pada saat studi pendahuluan tanggal 9 Agustus 2016 di Program Pascasarjana Universitas X Surabaya. Hasil studi pendahuluan menunjukkan bahwa pada tahun akademik 2015/2016 jumlah mahasiswa laki-laki sebanyak 10 orang dan mahasiswa perempuan sebanyak 21 (sumber: Bagian Administrasi Akademik Universitas X Surabaya).

Peneliti juga menemukan fenomena mahasiswa perempuan pada Program Pascasarjana di Universitas $\mathrm{X}$ Surabaya yang didominasi oleh mahasiswa yang bekerja dan berstatus menikah. Hasil studi pendahuluan tanggal 9 Agustus 2016 melalui wawancara dengan Direktur Program Pascasarjana di Universitas X Surabaya menunjukkan hasil sebagai berikut; (a) mahasiswa yang berstatus menikah sebanyak 3 orang; (b) mahasiswa yang bekerja dan berstatus menikah sebanyak 15 orang; dan (c) mahasiswa yang belum bekerja dan belum menikah sebanyak 2 orang. Berdasarkan data tersebut, dapat disimpulkan bahwa mahasiswa Program Pascasarjana di Universitas X Surabaya didominasi oleh mahasiswa perempuan yang berstatus menikah dan bekerja.

Mahasiswa yang berstatus menikah dan bekerja disebut berperan ganda. Adapun peran ganda mengacu pada konsep dualisme kultural yaitu adanya konsep domestic sphere (lingkungan domestik) dan public sphere (lingkungan publik) (Michele \& Louise, 1974). Adanya keinginan perempuan dalam menjalankan peran domestik di keluarga dan peran publik tersebut dapat menimbulkan kecenderungan konflik peran (Ruslina, 2014).

Konflik peran didefinisikan sebagai suatu bentuk konflik yang muncul antar peranan karena adanya peran ganda (Greenhaus \& Beutell, 1985). Relevansi munculnya konflik peran dengan status peran ganda tercantum dalam beberapa hasil penelitian, salah satunya penelitian Malhotra dan Sachdeva (2005) yang menunjukkan adanya pengaruh signifikan antara perempuan yang bekerja dengan munculnya konflik peran. Penelitian yang dilakukan Hidayah (2015) juga menunjukkan hasil bahwa mahasiswi yang telah menikah memiliki tanggung jawab pada peran domestik dan publik sehingga rentan terjadinya konflik antar peran.

Kajian tentang penyebab munculnya konflik peran tercantum dalam hasil penelitian Couzy (2012) yang menunjukkan bahwa kurangnya waktu sebagai penyebab terjadinya konflik peran. Hasil penelitian tersebut sesuai dengan pendapat Greenhaus dan Beutell (1985), bahwa salah satu faktor yang mempengaruhi terjadinya konflik peran adalah time based conflict, yaitu konflik peran karena waktu yang digunakan untuk memenuhi satu peran dapat mengurangi waktu untuk memenuhi kebutuhan peran lainnya.

Salah satu pemenuhan kebutuhan peran sebagai mahasiswa adalah pencapaian prestasi belajar, yaitu hasil penilaian dari kegiatan pembelajaran berupa simbol, angka, dan huruf sebagai bentuk evaluasi kemampuan mahasiswa dalam proses pembelajaran. Salah satu indikator prestasi belajar mahasiswa dapat dilihat dari indeks prestasi kumulatif (IPK) (Muhibbin, 2010). IPK diperoleh mahasiswa setelah diadakan evaluasi minimal dua semester.

Implikasi peran ganda terhadap prestasi belajar mahasiswa tercantum dalam penelitian Rohman (2010) melalui metode kualitatif. Hasil penelitian tersebut menunjukkan bahwa status peran ganda tidak berimplikasi negatif pada pencapaian prestasi belajar. IPK pada mahasiswa dengan peran ganda sebagai indikator pencapaian prestasi belajar diteliti oleh Permana (2011), yang menunjukkan hasil sebanyak 43,3\% dari mahasiswa dengan peran ganda mendapatkan IPK dengan predikat memuaskan. Penelitian Thomas, Raynor dan Al-Marzooqi (2012) juga menunjukkan hasil bahwa mahasiswa dengan 
peran ganda cenderung memiliki indeks prestasi yang lebih tinggi dibandingkan mahasiswa perempuan yang tidak berperan ganda.

Mengacu pada beberapa hasil penelitian yang telah diuraikan diatas, penulis melakukan studi pendahuluan untuk mengetahui implikasi peran ganda terhadap prestasi belajar mahasiswa. Studi pendahuluan dilakukan di Program Pascasarjana Universitas X Surabaya yang telah teridentifikasi didominasi oleh jumlah mahasiswa perempuan dengan peran ganda Hasil studi pendahuluan menunjukkan sebanyak 13 mahasiswa dari total jumlah keseluruhan 15 mahasiswa perempuan dengan peran ganda mendapatkan IPK diatas 3.50. Adapun IPK diatas 3.50 merupakan kriteria prestasi belajar dengan predikat memuaskan di Program Pascasarjana Universitas X Surabaya. Berdasarkan hasil studi pendahuluan tersebut, dapat disimpulkan bahwa mahasiswa dengan peran ganda di Universitas $\mathrm{X}$ Surabaya memiliki kecenderungan mencapai prestasi belajar tinggi, melalui perolehan IPK dengan predikat memuaskan.

Setiap mahasiswa dengan peran ganda mempunyai pengalaman dan tujuan yang berbeda-beda dalam mencapai prestasi belajarnya. Pengalaman tersebut juga dimaknai berbeda-beda menurut persepsi individu. Pemberian makna atas pengalaman individu merupakan bagian dari hasil analisis eksistensi individu melalui konsep manusia sadar yaitu nothingness yang berarti kesadaran dan tanggung jawab manusia atas keberadaannya (Sartre, 1965). Adanya perbedaan pemaknaan antar mahasiswa dengan peran ganda untuk memaknai pengalamannya dalam mencapai prestasi belajar disebabkan memaknai hidup adalah hal-hal yang memberikan arti khusus bagi individu, yang apabila berhasil dipenuhi akan menyebabkan kehidupannya berarti dan berharga (Budiharjo, 1997).

Berdasarkan kajian dari beberapa penelitian sebelumnya dan data-data yang diperoleh peneliti saat studi pendahuluan, diperoleh gambaran awal bahwa mahasiswa dengan peran ganda memiliki kecenderungan mencapai prestasi belajar yang tinggi berupa IPK dengan predikat memuaskan. Pengalaman dan tujuan dalam mencapai prestasi belajar tersebut dimaknai berbeda-beda oleh mahasiswa, sehingga penelitian ini akan mengkaji bentuk-bentuk pengalaman dalam mencapai prestasi belajar, serta pemberian nilai/arti terhadap pengalaman dalam mencapai prestasi belajar pada mahasiswa dengan peran ganda.

Pengalaman dalam mencapai prestasi belajar pada mahasiswa dengan peran ganda menarik untuk diteliti, karena setiap mahasiswa dengan peran ganda mempunyai pengalaman yang berbeda-beda dalam mencapai prestasi belajarnya. Pengalaman dalam mencapai prestasi belajar tersebut juga dimaknai menurut persepsi masing-masing individu. Penelitian ini dapat memberikan manfaat untuk memahami bentuk-bentuk pengalaman serta maknanya bagi mahasiswa dengan peran ganda dalam mencapai prestasi belajarnya. Dengan pemahaman tersebut, diharapkan dapat berimplikasi pada bentuk-bentuk perilaku mahasiswa yang mendukung untuk mencapai prestasi belajar yang diharapkan. Adanya fenomena tersebut yang mendasari penulis untuk melakukan penelitian yang berjudul "Makna Pencapaian Prestasi Belajar pada Mahasiswa Program Pascasarjana dengan Peran Ganda".

\section{Partisipan}

\section{E T O D E}

Teknik yang digunakan dalam penentuan partisipan penelitian adalah purposive sampling yaitu penentuan subjek/partisipan penelitian yang dipilih dengan kriteria dan tujuan tertentu. Secara rinci kriteria partisipan penelitian sebagai berikut:

a. Mahasiswa aktif Program Pascasarjana di Universitas X Surabaya;

b. Mahasiswa berjenis kelamin perempuan dengan status menikah dan bekerja;

c. Mahasiswa yang mendapatkan indeks prestasi kumulatif (IPK) $>3,50$. 
Selain kriteria tersebut, pemilihan partisipan penelitian juga berdasarkan hasil focus group discussion untuk mengetahui kinerja akademik dalam mencapai prestasi belajar, berupa perilaku mahasiswa yang mendukung pencapaian prestasi belajar yang diharapkan. Hal ini ditetapkan peneliti sebagai kriteria partisipan, untuk memenuhi kualifikasi aspek pengalaman mahasiswa dengan peran ganda yang mampu mencapai prestasi belajar melalui kinerja akademik yang mendukung pula. Berdasarkan kriteria yang ditetapkan dan data-data yang diperoleh peneliti pada studi pendahuluan, maka jumlah partisipan penelitian ditentukan sebanyak tiga mahasiswa.

\section{Prosedur}

Penelitian ini bertujuan untuk memahami pengalaman dan makna pencapaian prestasi belajar pada mahasiswa Program Pascasarjana dengan peran ganda. Metode yang digunakan adalah penelitian kualitatif atau naturalistik. Untuk memahami pengalaman dan makna pencapaian prestasi belajar pada mahasiswa dengan peran ganda, peneliti menggunakan metode penelitian kualitatif karena memiliki cakupan yang luas (breadth) dan kedalaman (depth) dalam mengungkap pengalaman-pengalaman individu. Adapun dalam penelitian ini menggunakan pendekatan fenomenologi.

Teknik pengumpulan data yang digunakan dalam penelitian ini adalah wawancara mendalam (in depth interview). Penulis melakukan wawancara semi terstruktur dengan cara wawancara mendalam (in depth interview). In depth dalam penelitian fenomenologi bermakna mencari sesuatu yang mendalam untuk mendapatkan satu pemahaman yang mendetail tentang pengalaman individu. Wawancara mendalam dalam penelitian ini diarahkan pada pemahaman sikap partisipan terhadap pengalaman dan makna dalam mencapai prestasi belajar sebagai mahasiswa dengan peran ganda.

Dalam penelitian ini, teknik pemantapan kredibilitas penelitian dilakukan dengan cara melakukan member check. Penggunaan member check sesuai dengan tujuan dalam penelitian yang berjudul "Makna Pencapaian Prestasi Belajar pada Mahasiswa Program Pascasarjana dengan Peran Ganda". Hal ini disebabkan, pengalaman dalam mencapai prestasi belajar bersifat individual sehingga fenomena yang terjadi juga berbeda antar partisipan. Adapun prosedur yang digunakan untuk mendapatkan kredibilitas penelitian sebagai berikut:

a. Peneliti melakukan wawancara awal pada setiap partisipan hingga mendapatkan data-data awal;

b. Pada wawancara selanjutnya, peneliti akan melakukan klarifikasi yang bertujuan untuk menyamakan persepsi antara peneliti dan partisipan.

\section{Analisis Data}

Data yang diperoleh peneliti melalui wawancara mendalam dianalisis dengan cara Interpretative Phenomenological Analysis (IPA) sebagaimana ditulis oleh Smith \& Osborn (2007). Adapun tahaptahapnya sebagai berikut: (1) Membaca dan membaca ulang transkrip; (2) Pencatatan awal; (3) Mengidentifikasi tema-tema yang muncul; (4) Mencari kaitan antara tema-tema; (5) Berpindah ke kasus lainnya; (6) Mencari pola antar kasus.

\section{Partisipan A}

\section{HAS I L P E N EL I T I A N}

Berdasarkan hasil penelitian pada partisipan A, maka dilakukan analisis data terhadap bentuk pengalaman dalam mencapai prestasi belajar dan makna pencapaian prestasi belajar sebagai

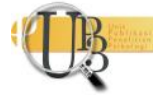


mahasiswa dengan peran ganda. Temuan penelitian tentang pengalaman dalam mencapai prestasi belajar menunjukkan hasil bahwa bentuk-bentuk pengalaman partisipan A meliputi tertib dalam presensi perkuliahan, mengerjakan tugas-tugas akademik secara mandiri, dan mempersiapkan diri mengikuti ujian. Tertib dalam presensi perkuliahan ditunjukkan melalui kehadiran mahasiswa dalam perkuliahan tatap muka yang harus dipenuhi jumlah minimal kehadirannya karena memberikan kontribusi terhadap penilaian prestasi belajar, berupa nilai partisipasi mahasiswa agar dapat mengikuti ujian. Mengerjakan tugas-tugas akademik secara mandiri ditunjukkan partisipan melalui perilaku yang menghindari plagiasi dan tidak mencontek tugas teman. Pengerjaan tugas secara mandiri diasumsikan partisipan dengan mengerjakan tugas dengan kemampuan diri sendiri dengan menghindari segala macam bentuk plagiasi. Mempersiapkan diri mengikuti ujian ditunjukkan partisipan A dengan meluangkan waktu sebelum ujian untuk membaca materi-materi yang telah diajarkan dalam perkuliahan.

Temuan penelitian tentang makna pencapaian prestasi belajar pada partisipan A meliputi meningkatkan harga diri, membuat bangga keluarga, dan mencapai jenjang karir. Meningkatkan harga diri sebagai makna pencapaian prestasi belajar pada karena partisipan A merupakan mahasiswa yang mendapatkan izin tugas belajar dari instansi, sehingga dengan mencapai prestasi belajar yang tinggi menjadi sesuatu yang membanggakan untuk pelaporan hasil belajarnya.

Membuat bangga keluarga sebagai makna pencapaian prestasi belajar karena adanya harapan keluarga agar partisipan melanjutkan karir di tempat orang tuanya bekerja membuat partisipan memaknai pencapaian prestasinya sebagai hal yang membanggakan untuk keluarganya yang telah memberikan harapan untuk karir berikutnya. Capaian prestasi belajar juga dimaknai partisipan untuk mencapai jenjang karir. Hal ini disebabkan, partisipan A memiliki keinginan untuk tetap bekerja setelah menyelesaikan Program Pascasarjana di Universitas X Surabaya. Oleh karena itu, pencapaian prestasi belajar dimaknai partisipan sebagai hal yang mendukung tujuannya dalam mencapai jenjang karir.

\section{Partisipan B}

Berdasarkan hasil penelitian pada partisipan B, maka dilakukan analisis data terhadap bentuk pengalaman dalam mencapai prestasi belajar dan makna pencapaian prestasi belajar sebagai mahasiswa dengan peran ganda. Temuan penelitian tentang pengalaman dalam mencapai prestasi belajar menunjukkan hasil bahwa bentuk-bentuk pengalaman partisipan B meliputi mengerjakan tugas perkuliahan secara mandiri, mempersiapkan diri mengikuti ujian, dan melengkapi literatur pembelajaran. Mengerjakan tugas perkuliahan secara mandiri ditunjukkan partisipan B dengan berusaha mengerjakan tugas sesuai dengan kemampuan dan bertanya kepada orang lain ketika menemui hambatan dalam pengerjaan tugas tersebut.

Mempersiapkan diri dalam ujian ditunjukkan partisipan B dengan memahami kekurangan diri sendiri ketika pembelajaran sehingga membaca materi yang telah diajarkan sebagai bentuk mempersiapkan diri untuk ujian. Melengkapi literatur pembelajaran untuk mendukung dalam mencapai prestasi belajar yang diharapkan juga termasuk pengalaman dalam pencapaian prestasi belajar. Hal tersebut ditunjukkan partisipan dengan mencari literatur secara mandiri yang mendukung pembelajaran meliputi buku-buku teks, jurnal, dan artikel.

Temuan penelitian tentang makna pencapaian prestasi belajar pada partisipan B meliputi: meningkatkan harga diri, membuat keluarga bangga, dan pencapaian jenjang karir berikutnya. Capaian prestasi belajar dimaknai sebagai upaya untuk meningkatkan harga diri disebabkan partisipan merupakan guru yang mendapatkan izin tugas belajar dari instansi tempatnya bekerja. Pencapaian prestasi belajar yang tinggi, dimaknai partisipan dapat meningkatkan harga diri di lingkungan kerja

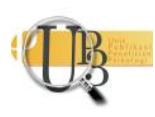


karena partisipan ingin membuktikan kepada pimpinan dan rekan-rekan kerjanya jika izin belajar yang diberikan instansi dimanfaatkannya dengan baik.

Membuat bangga keluarga sebagai makna pencapaian prestasi belajar pada partisipan B. Capaian prestasi belajar dimaknai partisipan sebagai sesuatu yang dapat membuat bangga bagi anak-anaknya yang tengah menempuh program sarjana dan sekolah menengah. Kebanggaan tersebut juga dimaknai partisipan dapat menjadi motivasi untuk berprestasi bagi anak-anaknya yang sedang menempuh pendidikan. Pemaknaan selanjutnya dalam mencapai prestasi belajar pada partisipan $\mathrm{C}$ adalah untuk mencapai jenjang karir. Setelah menyelesaikan Program Pascasarjana, partisipan memiliki keinginan untuk tetap bekerja dan menaikkan golongan pangkatnya sebagai guru. Oleh karena itu, pencapaian prestasi belajar dimaknai partisipan sebagai hal yang mendukung tujuannya dalam mencapai jenjang karir yang diharapkan.

\section{Partisipan $\mathrm{C}$}

Berdasarkan hasil penelitian pada partisipan C, maka dilakukan analisis data terhadap bentuk pengalaman dalam mencapai prestasi belajar dan makna pencapaian prestasi belajar sebagai mahasiswa dengan peran ganda. Hasil temuan penelitian tentang pengalaman dalam mencapai prestasi belajar menunjukkan hasil bahwa bentuk-bentuk pengalaman partisipan $\mathrm{C}$ meliputi mengerjakan tugastugas perkuliahan sesuai kemampuan, mempersiapkan diri mengikuti ujian, dan mengikuti perkuliahan sesuai dengan tata tertib akademik. Mengerjakan tugas-tugas perkuliahan seuai kemampuan sebagai salah satu bentuk pengalaman dalam mencapai prestasi belajar ditunjukkan dengan mengerjakan tugas sesuai dengan kemampuan diri sendiri. Partisipan memiliki pemahaman bahwa nilai tugas akademik mempunyai kontribusi dalam menentukan IPK.

Mempersiapkan diri untuk mengikuti ujian sebagai bentuk pengalaman pada partisipan C ditunjukkan dengan waktu yang diluangkan partisipan untuk belajar sebagai bentuk persiapan diri dalam ujian. Partisipan memiliki pemahaman jika nilai ujian memberikan kontribusi terhadap pencapaian IPK, sehingga partisipan mempersiapkan dirinya dengan baik untuk mengikuti ujian. Mengikuti perkuliahan sebagai bentuk pengalaman dalam mencapai prestasi belajar pada partisipan C. Hal ini ditunjukkan dengan kehadiran partisipan dalam mengikuti perkuliahan tatap muka. Meskipun memiliki kesibukan yang tinggi dengan peran gandanya, partisipan menghindari untuk membolos dalam perkuliahan. Partisipan beranggapan bahwa, nilai kehadiran dalam perkuliahan juga memberikan kontribusi terhadap pencapaian nilai IPK.

Temuan penelitian tentang makna pencapaian prestasi belajar pada partisipan C meilputi: meningkatkan harga diri, membuat bangga keluarga, dan mencapai jenjang karir. Capaian prestasi belajar dimaknai partisipan untuk meningkatkan harga diri. Hal ini disebabkan, partisipan merupakan mahasiswa yang mendapatkan izin tugas belajar dari instansi tempatnya bekerja. Capaian prestasi belajar dimaknai partisipan dapat meningkatkan harga diri di lingkungan kerja ketika membuat laporan tugas belajar kepada pimpinan.

Partisipan C memaknai pencapaian prestasi belajar untuk membuat bangga keluarga. Pencapaian prestasi belajar yang tinggi, dimaknai partisipan sebagai hal yang membanggakan agar dapat memotivasi anaknya yang juga sedang menempuh Program Pascasarjana. Selain itu, partisipan C juga memaknai capaian prestasi belajar untuk mencapai jenjang karir. Pengalaman gagal dalam seleksi PNS membuat partisipan ingin mencapai jenjang karir lebih lanjut setelah menyelesaikan Program Pascasarjana. Oleh karena itu, pencapaian prestasi belajar dimaknai partisipan sebagai hal yang mendukung tujuannya dalam mencapai jenjang karir. 


\section{I S K U S I}

Berdasarkan hasil analisis data terhadap ketiga partisipan, diperoleh gambaran bentuk-bentuk pengalaman dalam mencapai prestasi belajar, dan makna pencapaian prestasi belajar pada mahasiswa dengan peran ganda. Sebelumnya dapat terangkum latar belakang partisipan sebagai mahasiswa dengan peran ganda di Program Pascasarjana Universitas X Surabaya. Berdasarkan hasil temuan penelitian, mahasiswa dengan peran ganda dalam penelitian ini mencakup peran publik dan peran publik sebagai berikut; (a) peran sebagai mahasiswa Program Pascasarjana di Universitas X Surabaya; (b) peran sebagai wanita karir di instansi masing-masing partispan; dan (c) peran sebagai istri dan ibu di keluarga.

Sebagai mahasiswa dengan peran ganda, ketiga partisipan konflik peran ganda dipengaruhi oleh faktorfaktor yang berbeda-beda. Adapun faktor-faktor yang mempengaruhi konflik peran ganda sebagai berikut yaitu; (1) time-based conflict, konflik peran karena waktu yang digunakan untuk memenuhi satu peran dapat mengurangi waktu untuk memenuhi kebutuhan peran lainnya; (2) strain based conflict, konflik peran karena adanya tekanan dari salah satu peran mempengaruhi kinerja peran lainnya; (3) behaviour based conflict, konflik peran karena adanya ketidaksesuaian antara pola perilaku dengan tujuan yang diinginkan dari peran ganda tersebut (Greenhaus \& Beutell, 1985).

Partisipan A mengalami konflik peran disebabkan waktu yang digunakan memenuhi kebutuhan peran sebagai guru dan kepala sekolah lebih mendominasi daripada waktu untuk pemenuhan kebutuhan peran sebagai mahasiswa dan peran sebagai ibu dan istri di keluarga. Adanya konflik tersebut tidak berpengaruh terhadap pencapaian prestasi belajar partisipan, karena partisipan menggunakan waktu istirahat di tempat kerja untuk mengerjakan tugas kuliah. Kemudian selesai bekerja dan kuliah, semua waktu yang dimiliki partisipan digunakan untuk keluarga. Partisipan B mengalami konflik peran disebabkan adanya tekanan dari perannya sebagai guru berstatus PNS dengan beban kerja yang harus dipenuhi. Sedangkan partisipan C mengalami konflik peran disebabkan waktu untuk memenuhi kebutuhan setiap peran tidak seimbang dan adanya ketidaksesuaian perilaku dalam memenuhi kebutuhan peran.

Dalam penelitian ini juga membahas prestasi belajar pada mahasiswa Program Pascasarjana dengan peran ganda. Prestasi merupakan suatu tingkatan khusus dari kesuksesan individu karena mempelajari tugas-tugas, atau tingkat tertentu dari kecakapan dalam tugas akademis (Chaplin, 2006). Berdasarkan hasil temuan dalam penelitian, prestasi belajar sebagai mahasiswa dioprasionalkan ketiga partisipan dalam bentuk IPK. Menurut Azwar (2004), faktor-faktor yang mempengaruhi prestasi belajar meliputi faktor internal dan faktor eksternal. Faktor internal terdiri dari faktor fisik yang berhubungan dengan kondisi fisik dan faktor psikologis yang berhubungan dengan faktor-faktor non fisik, yaitu minat, bakat, kesehatan mental, dan motivasi. Faktor eksternal terdiri dari faktor fisik, yang menyangkut kondisi tempat belajar, sarana dan perlengkapan belajar, materi pembelajaran, dan kondisi lingkungan belajar. Faktor sosial terdiri dari dukungan sosial dan pengaruh budaya.

Temuan dari penelitian menunjukkan bahwa ketiga partisipan mengalami faktor internal yang sama yaitu motivasi, namun dalam bentuk yang berbeda-beda antar partisipan. Partisipan A menganggap dukungan dan harapan orang tua sebagai bentuk motivasi berprestasi untuk mencapai prestasi belajar, sedangkan partisipan B termotivasi karena suaminya yang telah selesai menempuh pendidikan Program Pascasarjana dan capaian prestasi belajarnya dimaknai dapat memotivasi anak-anaknya untuk berprestasi. Pada partisipan $\mathrm{C}$, capaian prestasi belajar membuatnya termotivasi untuk mengikuti seleksi PNS sebagai jenjang karir berikutnya dan capaian prestasi belajarnya dimaknai dapat memotivasi anaknya yang sedang menempuh pendidikan Program Pascasarjana untuk berprestasi dalam studinya.

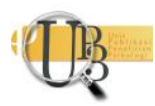


Pemaknaan terhadap pencapaian prestasi belajar pada mahasiswa dengan peran ganda ditentukan berdasarkan komponen-komponen tertentu. Menurut Bastaman (2007), terdapat enam komponen dalam menentukan makna yaitu; (1) pemahaman diri (self insight); (2) makna hidup (the meaning of life); (3) pengubahan sikap (changing attitude); (4) komitmen diri (self commitment); (5) kegiatan terarah (directed activities); dan dukungan sosial (social support).

Berdasarkan hasil temuan dalam penelitian, partisipan A menentukan makna pencapaian prestasi belajar berdasarkan komponen dukungan sosial yang bersumber dari suami dan anaknya, serta harapan orang tuanya agar partisipan melanjutkan jenjang karir di tempat orang tuanya bekerja. Partisipan B dan C menentukan makna pencapaian prestasi belajar berdasarkan komponen pemahaman diri dan dukungan sosial. Pemahaman diri berupa meningkatnya kesadaran atas kekurangan diri sendiri yang cenderung pelupa terhadap materi perkuliahan dan keinginan kuat untuk membaca kembali materi tersebut sebagai upaya mempersiapkan diri menghadapi ujian.

Pemaknaan pencapaian prestasi belajar pada mahasiswa dengan peran ganda bersumber pada penilaian individu terhadap sesuatu yang dialami, meliputi; (1) nilai-nilai kreatif (creative values); nilai yang dapat diperoleh individu melalui bekerja maupun berkarya serta melaksanakan tugas dengan keterlibatan dan tanggung jawab pada pekerja; (2) nilai-nilai pengalaman (experiential values); nilai yang diperoleh individu dengan cara menerima segala yang ada dengan penuh kesadaran dan penghayatan yang mendalam; (3) nilai-nilai bersikap (attitudinal values); nilai yang diperoleh individu dengan mengambil sikap terhadap keadaan yang tidak bisa dihindari (Frankl, 1988).

Capaian prestasi belajar pada mahasiswa dengan peran ganda juga dapat dimaknai dengan berorientasi pada pemenuhan kebutuhan individu yang berjenjang membentuk hirarki, berupa basic need dan growth needs, meliputi; (1) physiological needs, yaitu kebutuhan yang bersifat biologis; (2) safety needs, yaitu kebutuhan akan rasa aman; (3) social needs, yaitu kebutuhan-kebutuhan sosial untuk ikut serta (sense of participation) dan kebutuhan untuk dapat berprestasi; (4) esteem needs, yaitu kebutuhan akan harga diri; dan (5) self actualization, yaitu kebutuhan untuk pengembangan pribadi yang fungsional terhadap lingkungan (Maslow, 1954). Capaian prestasi belajar pada mahasiswa dengan peran ganda juga dapat dimaknai dengan berorientasi pada dominasi kebutuhan individu meliputi: (1) kebutuhan untuk bersahabat (need for affiliation); (2) kebutuhan untuk berkuasa (need for power), dan (3) kebutuhan untuk berprestasi (need for achievement).

Berdasarkan hasil temuan penelitian, makna pencapaian prestasi belajar pada ketiga partisipan bersumber dari berbagai hal, yaitu nilai-nilai kreatif ditunjukkan dengan adanya keinginan untuk tetap bekerja dan mencapai jenjang karir selanjutnya pada ketiga partisipan. Selain itu partisipan juga ingin meningkatkan harga diri sebagai bentuk orientasi pada pemenuhan kebutuhan pada jenjang esteem needs. Temuan yang berbeda terletak pada partisipan A yang memaknai dukungan keluarga dan harapan orang tua dalam menempuh jenjang karir berikutnya sebagai motivasi untuk berprestasi sehingga mencapai prestasi belajar yang tinggi. Partisipan B dan C memaknai capaian prestasi belajarnya sebagai hal yang dapat membuat anak-anaknya termotivasi untuk berprestasi.

Penelitian ini bertujuan untuk memahami pengalaman dan makna pencapaian prestasi belajar pada mahasiswa Program Pascasarjana dengan peran ganda. Wawancara mendalam sebagai teknik penggalian data penelitian diarahkan pada pertanyaan tentang pengalaman dalam mencapai prestasi belajar, serta makna pencapaian prestasi belajar tersebut. Hasil temuan penelitian tentang bentukbentuk pengalaman dalam mencapai prestasi belajar meliputi: (1) tertib presensi perkuliahan; (2) mengumpulkan tugas tepat waktu; (3) mempersiapkan diri mengikuti ujian; dan (4) melengkapi litertur dalam pembelajaran. Hasil penelitian tentang makna pencapaian prestasi belajar pada mahasiswa Program Pascasarjana dengan peran ganda meliputi: (1) Meningkatkan harga diri; (2) Membuat bangga keluarga; dan (3) Mencapai jenjang karir. Hasil penelitian tentang pengalaman dan makna pencapaian

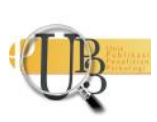


prestasi belajar pada mahasiswa dengan peran ganda menunjukkan temuan dengan tema yang sama, namun dengan bentuk pengalaman dan makna yang berbeda-beda antar partisipan.

\section{S I M P U L A N}

Penelitian ini bertujuan untuk memahami makna dan pengalaman dalam mencapai prestasi belajar pada mahasiswa dengan peran ganda. oleh karena itu, temuan dalam penelitian ini sesuai dengan tujuan penelitian yang dibagi dalam dua bentuk, yaitu; (1) temuan tentang pengalaman dalam mencapai prestasi belajar pada mahasiswa dengan peran ganda; dan (2) temuan tentang makna dari pengalaman dalam mencapai prestasi belajar pada mahasiswa dengan peran ganda. Temuan pengalaman dalam mencapai prestasi belajar pada mahasiswa dengan peran ganda meliputi tertib presensi perkuliahan, mengerjakan tugas tepat waktu, mempersiapkan diri untuk mengikuti ujian, dan melengkapi literatur yang mendukung pembelajaran.

Temuan pemaknaan dalam mencapai prestasi belajar pada mahasiswa dengan peran ganda yaitu meningkatkan harga diri, membuat bangga keluarga, dan mencapai jenjang karir. Meningkatkan harga diri sebagai makna dalam mencapai prestasi belajar, karena ketiga partisipan memiliki latar belakang yang sama sebagai wanita yang telah bekerja dan mendapatkan izin belajar dari instansi masing-masing. Adanya pencapaian prestasi belajar yang tinggi, dimaknai partisipan dapat meningkatkan harga diri didepan pimpinan, rekan kerja (guru sejawat), dan prestasi yang membanggakan untuk diceritakan kepada siswa. Membuat bangga keluarga sebagai makna pencapaian prestasi belajar, karena ketiga partisipan memiliki latar belakang yang sama yaitu keluarga yang memberi dukungan terhadap studinya.

Pencapaian prestasi belajar dimaknai partisipan dapat membuat bangga orang tua dan suami yang telah ikut andil dalam membuat keputusan partisipan untuk menempuh Program Pascasarjana. Selain itu, kebanggaan tersebut dimaknai partisipan karena dengan mencapai prestasi belajar diharapkan dapat membuat anak-anak partisipan menjadi termotivasi untuk berprestasi dalam menempuh pendidikannya masing-masing. Temuan yang berbeda pada ketiga partisipan terletak pada orientasi tujuan dukungan keluarga berupa arah tujuan karir sebagai harapan keluarga pada masing-masing partisipan. Capaian prestasi belajar dimaknai partisipan sebagai hal yang mendukung untuk mencapai jenjang karir sesuai dengan kualifikasi pekerjaan yang berbeda-beda antar partisipan. Temuan yang berbeda terletak pada capaian jenjang karir yang diharapkan, meliputi jenjang karir sebagai dosen, jenjang karir untuk golongan/pangkat PNS, dan jenjang karir untuk mengikuti seleksi PNS.

Saran untuk penelitian selanjutnya yaitu pada proses studi pendahuluan sebaiknya tidak menggunakan satu instrumen saja. Seperti dalam penelitian ini, menggunakan teknik wawancara dalam studi pendahuluan, hal tersebut perlu menjadi evaluasi dalam penelitian. Hal ini disebabkan, proses wawancara pada saat studi pendahuluan sering mengalami bias karena informan yang kurang tepat. Oleh karena itu, adanya penggunaan instrumen lain untuk mendukung hasil wawancara studi pendahuluan sangat membantu dalam pengumpulan data awal penelitian.

\section{P US T AKA A C UAN}

Azwar, S. (2004). Pengantar Psikologi Intelegensi. Yogyakarta: Pustaka Pelajar.

Bastaman, H.D. (2007). Logoterapi: Psikologi untuk Menemukan Makna Hidup dan Meraih Hidup Bermakna. Jakarta: PT. Raja Grafindo.

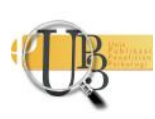


Budiharjo, P. (1997). Mengenal Teori Kepribadian Mutakhir. Yogyakarta: Kanisius.

Boyatzis, R.E. (1998). Transforming Qualitative Information: Thematic Analysis and Code Development. Sage Publication.

Chaplin, J.P. (2005). Kamus Lengkap Psikologi. Terjemahan Kartini Kartono. Jakarta : Raja Grafindo.

Creswell, J.W. (1994). Research Design: Qualitative \& Quantitative Approaches. New Delhi India: Sage Publications India Pvt. Ltd.

Couzy, M. (2012). Conflicting Roles: Balancing Family and Professional Life-a Chalengge for Working Women. Linnaeus University: Thesis School of Business and Economics.

Fakih, M. (1996). Analisis Gender dan Transformasi Sosial. Yogyakarta: Pustaka Pelajar Offset.

Frankl, F.E. (1988). The Will to Meaning, Foundations and Applications of Logotherapy. New York: Meridian.

Greenhaus, J. H., \& Beutell, N. J. (1985). Sources of conflict between work and family roles. Academy of management review, 10(1), 76-88.

Hidayah, L. (2015). Konflik Peran Ganda Mahasiswi Sosiologi FISIP Universitas Jember yang Telah Menikah. Naskah Publikasi. Universitas Jember.

Malhotra, S., \& Sachdeva, S. (2005). Social roles and role conflict: An interprofessional study among women. Journal of the Indian Academy of Applied Psychology, 31(1-2), 37-42.

Michelle, Z. R. \& Louise. L. (1974). Women, Culture and Society. Stanford: Stanford University Press.

Muhibbin, S. (2010). Psikologi Pendidikan dengan Pendekatan Baru. Bandung: PT Remaja Rosdakarya.

Permana, H.D. (2011). Konflik Peran Ganda dan Prestasi Belajar pada Mahasiswa yang Bekerja di Pizza Hut Semarang. Naskah Publikasi. Universitas Negeri Semarang.

Ruslina. (2014). Hubungan Antara Konflik Peran Ganda Dengan Stres Kerja Pada Wanita Bekerja. Naskah Publikasi. Universitas Muhammadiyah Surakarta.

Rohman, N.H. (2010). Implikasi Pernikahan pada Masa Studi Terhadap Prestasi Belajar. Naskah Publikasi. Universitas Islam Negeri Sunan Kalijaga Yogyakarta.

Sartre, J. P. (1965). Essays in Existentialism. Citadel Press.

Smith, J. A., \& Osborn, M. (2007). Interpretative Phenomenological Analysis. In J. A. Smith (Ed.), Qualitative Psychology: Practical Guide to Research Method. London : SAGE Publications.

Thomas, J., Raynor, M., \& Al-Marzooqi, A. (2012). Marital Status and Gender as Predictors Of Undergraduate Academic Performance: a United Arab Emirates Context. Learning and Teaching in Higher Education: Gulf Perspectives (2). Diakses dari http://lthe.zu.ac.ae

Tjiptoherijanto, P. (1997). Migrasi, Urbanisasi dan Pasar Kerja di Indonesia. Jakarta: Penerbit Universitas Indonesia Press.

Yin, R. K. (1997). Studi Kasus (Desain dan Metode). Jakarta: Raja Grafindo Persada. 